\title{
Distribution and Availability of Copper, Iron, Manganese and Zinc in the Archaeological Black Earth Profile from the Amazon Region
}

\author{
Cleide S. T. Mescouto, ${ }^{a}$ Vanda P. Lemos, ${ }^{a}$ Heronides A. Dantas Filho, ${ }^{a}$ \\ Marcondes L. da Costa, ${ }^{b}$ Dirse C. Kern ${ }^{c}$ and Kelly G. Fernandes ${ }^{*, a}$ \\ ${ }^{a}$ Faculdade de Química, Instituto de Ciências Exatas e Naturais and ${ }^{b}$ Instituto de Geociências, \\ Universidade Federal do Pará, 66075-110 Belém-PA, Brazil
}

'Museu Paraense Emílio Goeldi, 66077-830 Belém-PA, Brazil

\begin{abstract}
Os solos de terra preta arqueológica são ricos em matéria orgânica, contêm fragmentos cerâmicos e artefatos líticos e apresentam nutrientes em concentrações mais elevadas do que outros tipos de solos. Com o intuito de contribuir com informações sobre concentrações de micronutrientes disponíveis em solos de terra preta, foram avaliadas através de extrações químicas sequenciais, a distribuição e disponibilidade de $\mathrm{Cu}, \mathrm{Fe}, \mathrm{Mn}$ e $\mathrm{Zn}$ em um perfil de terra preta arqueológica no município de Juruti, estado do Pará. As maiores concentrações de $\mathrm{Cu}, \mathrm{Fe}, \mathrm{Mn}$ e $\mathrm{Zn}$ no perfil são encontradas na fração residual. Este estudo mostrou que ferro, manganês e zinco são preferencialmente disponíveis a partir das frações, associados aos óxidos de Fe-Mn, variando de 1265,39 a $1818,12 \mathrm{mg} \mathrm{kg}^{-1}, 0,83$ a 48,51 $\mathrm{mg} \mathrm{kg}^{-1}$ e 1,92 a 12,05 $\mathrm{mg} \mathrm{kg}^{-1}$, respectivamente, e o cobre a partir da matéria orgânica, variando de 0,13 a $0,45 \mathrm{mg} \mathrm{kg}^{-1}$.
\end{abstract}

The archaeological black earth soils are rich in organic matter, contain ceramic fragments and lithics artifacts and feature nutrients in higher concentrations than other types of soils. To contribute information about micronutrient concentrations available in black earth soils, the distribution and availability of $\mathrm{Cu}, \mathrm{Fe}, \mathrm{Mn}$ and $\mathrm{Zn}$ in the archaeological black earth profile from the municipal district of Juruti, Pará State, was evaluated through sequential chemical extractions. The largest concentrations of $\mathrm{Cu}, \mathrm{Fe}, \mathrm{Mn}$ and $\mathrm{Zn}$ in the profile are found in the residual fraction. This study showed that the iron, manganese and zinc are preferentially available from the fractions associated with Fe-Mn oxides ranging from 1265.39 to $1818.12 \mathrm{mg} \mathrm{kg}^{-1}, 0.83$ to $48.51 \mathrm{mg} \mathrm{kg}^{-1}$ and 1.92 to $12.05 \mathrm{mg} \mathrm{kg}^{-1}$ respectively, and the copper from organic matter, ranging from 0.13 to $0.45 \mathrm{mg} \mathrm{kg}^{-1}$.

Keywords: archaeological black earth, distribution, metals, availability, FAAS

\section{Introduction}

The terra preta anthrosols of Amazonia are mainly oxisols, ultisols and inceptisols with an anthropic A horizons ${ }^{1}$ with dark colouration, popularly called idian black earth (IBE) or archaeological black earth (ABE), ${ }^{2}$ occur mainly in the Brazilian Amazon, Colombia, and, less frequently, Venezuela, Peru, and Guiana. ${ }^{3}$ The areas in which ABE occurs is characterized by well-drained soil, running water and located in a particular geographical setting from which the surrounding areas can be clearly observed. ${ }^{4}$ Several hypotheses have been suggested on the process of ABE formation; however, the most widely accepted states that $\mathrm{ABE}$ would have been formed

*e-mail: kdgfernandes@ufpa.br unintentionally by pre-Columbian man. ${ }^{5}$ Human activity in the pre-Columbian past has resulted in the accumulation of plant and animal residues, as well as large quantities of ceramic and lithic artifacts, ash, charcoal, and various chemical elements, such as $\mathrm{P}, \mathrm{Mg}, \mathrm{Zn}, \mathrm{Cu}, \mathrm{Ca}, \mathrm{Sr}$ and $\mathrm{Ba}$, representing the geochemical signature of human occupation. These accumulations probably contributed decisively to the formation of fertile soils, ${ }^{6}$ with high concentrations of available phosphorus and calcium and low concentrations of $\mathrm{Al}$ (III) cause the plants to develop better in black earth ${ }^{7}$ compared with the adjacent non anthropogenic soils.

Several chemical elements in soils are physiologically essential for growth and vegetal reproduction. ${ }^{8}$ Elements such as copper, iron, manganese, and zinc are essential to biological systems, but can produce toxic effects when 
absorbed in high quantities; ${ }^{9}$ therefore, knowledge on the availability of these elements in soil is of fundamental importance.

The total content of metals in soil is generally not a suitable index for estimating their availability in soils, because only part of them is mobile in the soil profile and is available for absorption by the roots of plants. ${ }^{10}$ These metals can accumulate in the soil in different forms such as water-soluble, exchangeable, bound to oxides, bound to carbonates, and bound to organic and residual matter in the structure of minerals. ${ }^{11}$ Water-soluble and exchangeable fractions are considered readily mobile and available; fractions associated to oxides, carbonates, and organic matter may be potentially available,,$^{12}$ depending on the combination of chemical and physical properties of the soil, ${ }^{10}$ while the residual fraction is not available to plants and microorganisms. ${ }^{12}$ One of the tools used to evaluate the different chemical forms of metals in soil is the sequential extraction methods..$^{11}$ These methods are commonly used for the fractionation of metals in soils, sediments, and other environmental matrices and to evaluate the potential mobility and availability of these metals..$^{13}$ The principle of the sequential extraction method consists of sequentially applying appropriate chemical reagents, where each step of the sequence is chemically more aggressive than the previous one. ${ }^{14}$ Each method has a set of reagents which specifically attacks the geochemical form by which it is chemically bound to the soil structure. ${ }^{11}$ The information obtained allows the phyto-bioavailability, phytotoxicity, dynamics of trace elements, and transformations between the different chemical forms in polluted or tillable soils to be assessed. ${ }^{15}$

The aim of this study was to evaluate the distribution and availability of copper, iron, manganese, and zinc among different fractions in the soil profile of ABE from Juruti-PA.

\section{Experimental}

Study area

The study was conducted with archaeological black earth (ABE) profile samples obtained in the terra preta archaeological site 2 , in the rainy season, in an area in the municipality of Juruti (PA) on the right bank of the Amazon River. Located in the western State of Pará, Brazil, the municipality has an estimated population of 38,000 inhabitants in an area of $8342 \mathrm{~km}^{2}, 848 \mathrm{~km}$ away from the capital Belém. Prospecting site terra preta 2 was based on the application of systematic sampling distributed in vertical lines, towards the east. Along these lines, towards the south, were made polls belonging to lines 480E, 360E, 240E, $120 \mathrm{E}$, according to the Figure 1. For a refined understanding of archeological study, three areas were opened called excavation unit 1,2 and 5. Furthermore, it was opened a soil profile, object of study of this work, which was described and collected following the soil horizons. The location of the soil profile is at the geographical coordinates UTM $21 \mathrm{M}$ 599557E and 9759353N.

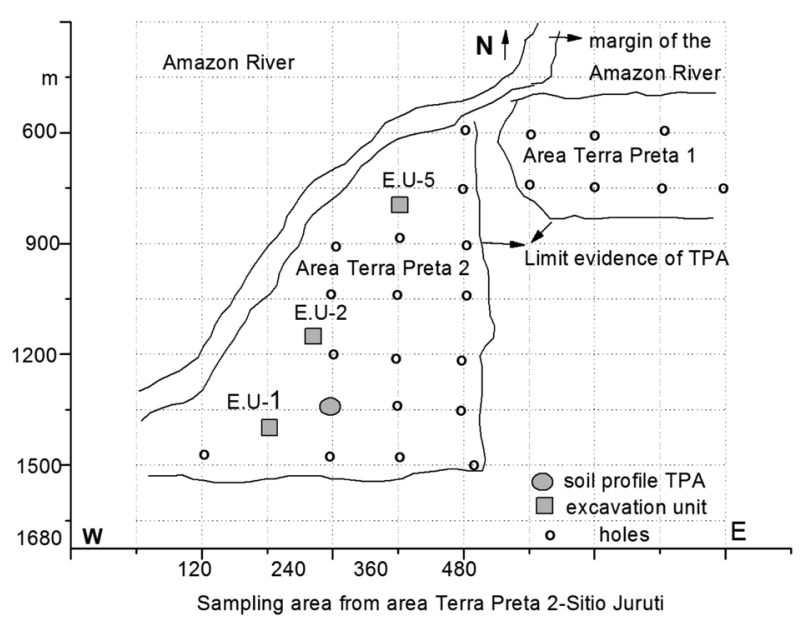

Figure 1. Location of black earth site 2 in the municipality of Juruti.

\section{Soil samples}

Morphological description of soil horizons were classified according to standards recommended by the Brazilian Society of Soil Sciences ${ }^{16}$ and colors samples were determined according to Munsell. ${ }^{17}$ Soil samples were air dried, lumps were removed, and the samples were passed through a $2 \mathrm{~mm}$ sieve. The $\mathrm{pH}$ values in water and organic matter were determined according to the methods of Embrapa. ${ }^{18}$ The $\mathrm{pH}$ of samples in water was determined by the direct potentiometric method using a soil:water ratio of 1:2.5 after $1 \mathrm{~h}$ of rest and shaking before reading. The organic matter content was determined by the oxidationreduction method using potassium dichromate as the oxidant of organic matter.

\section{Reagents and materials}

All solutions were prepared using deionized water (resistivity of $18.2 \mathrm{M} \Omega \mathrm{cm}$ ) purified by an ELGA system (Elgastat, Bucks, England). For extraction procedures, the following analytical grade reagents were used: magnesium chloride $\left(\mathrm{MgCl}_{2}\right.$, Nuclear, São Paulo, Brazil), sodium acetate (NaOAc, Nuclear), hidroxylamine chloride $\left(\mathrm{NH}_{2} \mathrm{OH} \cdot \mathrm{HCl}\right.$, Nuclear), acetic acid (HOAc, Impex, São Paulo, Brazil), 
hydrogen peroxide $\left(\mathrm{H}_{2} \mathrm{O}_{2}\right.$, Impex $)$ ammonium acetate $\left(\mathrm{NH}_{4} \mathrm{OAc}\right.$, Vetec, Rio de Janeiro, Brazil), nitric acid $\left(\mathrm{HNO}_{3}\right.$ $65 \% \mathrm{v} / \mathrm{v}$, Impex), hydrochloric acid ( $\mathrm{HCl} 37 \% \mathrm{v} / \mathrm{v}$, Impex) and hydrofluoric acid (HF 40\% v/v, Quimex, São Paulo, Brazil).

Appropriate buffer solutions ( $\mathrm{pH} 4.0$ and $\mathrm{pH}$ 7.0) were used for calibrating the pHmeter.

The analytical curves were prepared from standard solutions of $1000 \mathrm{mg} \mathrm{L}^{-1}$ for all elements (J. T. Baker). All glassware and bottles used in the procedures were immersed in $10 \%(\mathrm{v} / \mathrm{v}) \mathrm{HNO}_{3}$ solution for $24 \mathrm{~h}$ and thoroughly rinsed with deionized water.

The sequential extractions were performed using horizontal mechanical shaker Model 3520 (LAB-Line, USA) and centrifuges Model 80-2B (Centribio, Brazil)

\section{Analytical procedure}

\section{Sequential extraction}

The sequential extraction procedure of Ma and Rao, ${ }^{19}$ which is a modified version of the method described by Tessier et al., ${ }^{11}$ was used to separate the metals into six fractions which were denoted as F1, F2, F3, F4, F5, and F6.

Approximately $1 \mathrm{~g}$ of each sample from the ABE profile was weighed in triplicate and transferred to centrifuge tubes of $15 \mathrm{~mL}$ and then the following sequential extraction was carried out. (i) Water-soluble fraction (F1): the soil was extracted with $10 \mathrm{~mL}$ of deionized water for $2 \mathrm{~h}$ in a horizontal shaker at room temperature. (ii) Exchangeable fraction (F2): the residue obtained in F1 was extracted with $10 \mathrm{~mL}$ of $\mathrm{MgCl}_{2}$ solution $1.0 \mathrm{~mol} \mathrm{~L}^{-1}$ (pH 7.0) for $1 \mathrm{~h}$ in a horizontal shaker at room temperature. (iii) Fraction bound to carbonates (F3): the residue obtained in F2 was extracted with $10 \mathrm{~mL}$ of sodium acetate solution $(\mathrm{NaOAc}) 1.0 \mathrm{~mol} \mathrm{~L}^{-1}$ (pH 5) for $5 \mathrm{~h}$ in a horizontal shaker at room temperature. (iv) Fraction bound to Fe-Mn oxides (F4): the residue obtained in $\mathrm{F} 3$ was extracted with $10 \mathrm{~mL}$ of hydroxylamine chloride solution $\left(\mathrm{NH}_{2} \mathrm{OH} \cdot \mathrm{HCl}\right) 0.04 \mathrm{~mol} \mathrm{~L}^{-1}$ in acetic acid (HOAc) $25 \%(\mathrm{v} / \mathrm{v})$ for $5 \mathrm{~h}$ at $96{ }^{\circ} \mathrm{C}$ under slow agitation. (v) Fraction bound to organic compounds (F5): the residue obtained in $\mathrm{F} 4$ was extracted with $10 \mathrm{~mL} \mathrm{H}_{2} \mathrm{O}_{2} 30 \%(\mathrm{~m} / \mathrm{m})$ at $\mathrm{pH} 2.0$ (adjusted with $\mathrm{HNO}_{3}$ ) for $5.5 \mathrm{~h}$ in a water bath at $85{ }^{\circ} \mathrm{C}$ under slow agitation. After this time, the samples were cooled, $2.5 \mathrm{~mL}$ of ammonium acetate $\left(\mathrm{NH}_{4} \mathrm{OAc}\right)$ $3.2 \mathrm{~mol} \mathrm{~L}^{-1}$ in $\mathrm{HNO}_{3} 20 \%(\mathrm{v} / \mathrm{v})$ were added, and samples were then stirred for $30 \mathrm{~min}$. (vi) Residual fraction (F6): the residue obtained in $\mathrm{F} 5$ was placed to dry in oven at $60{ }^{\circ} \mathrm{C}$ for $24 \mathrm{~h}$ and removed from the centrifuge tubes. The digestion of the residue was performed by adding $16 \mathrm{~mL}$ of Lefort water $\left(3 \mathrm{HNO}_{3}: 1 \mathrm{HCl}\right)$, and after $12 \mathrm{~h}$ of rest the samples were heated for $8 \mathrm{~h}$ at a temperature of $160{ }^{\circ} \mathrm{C}$.
The digested part and the residue (silicate compounds that were not digested) were quantitatively transferred into a centrifuge tube of $50 \mathrm{~mL}$ with the addition of $10 \mathrm{~mL}$ of deionized water. The separation of the supernatant and residue was carried out by centrifugation at $2000 \mathrm{rpm}$ for $5 \mathrm{~min}$. The residue was dissolved at room temperature by adding $2 \mathrm{~mL}$ of concentrated $\mathrm{HF}$, and after dissolution, $1 \mathrm{~g}$ of $\mathrm{H}_{3} \mathrm{BO}_{4}$ was added for the complexation of the remaining fluoride. The resulting mixture was added to the previously collected supernatant (liquid phase of the digested part) and the volume was adjusted to $50 \mathrm{~mL}$ with deionized water.

At the end of each extraction process (fractions F1, F2, F3, F4, and F5), the separation of the residue and supernatant was carried out by centrifugation at $3000 \mathrm{rpm}$ for $30 \mathrm{~min}$. The supernatants were removed with a pipette and filtered through Whatman filter paper no. 42. All solid phases were washed with $5 \mathrm{~mL}$ of deionized water before the next extraction. Washes were collected and analysed with the supernatant from the previous fraction. All experiments were performed in triplicate.

\section{Instrumentation}

All determinations of metals were performed using a flame atomic absorption spectrometer (FAAS) (Model AA 220, Varian, Australia) equipped with $\mathrm{Cu}, \mathrm{Fe}, \mathrm{Mn}$ and $\mathrm{Zn}$ hollow cathode lamps and an air-acetylene flame. The instrumental conditions are shown in Table 1.

Table 1. Operational condition for FAAS

\begin{tabular}{lcccc}
\hline Parameters & $\mathrm{Cu}$ & $\mathrm{Fe}$ & $\mathrm{Mn}$ & $\mathrm{Zn}$ \\
\hline Wavelength / nm & 324.8 & 248.3 & 279.5 & 213.9 \\
Lamp current / mA & 4.0 & 14.0 & 15.0 & 10.0 \\
Spectral resolution / nm & 0.5 & 0.2 & 0.2 & 1.0 \\
\hline
\end{tabular}

Addition of $4.0 \mathrm{mg} \mathrm{L}^{-1} \mathrm{Cu}, 9.0 \mathrm{mg} \mathrm{L}^{-1} \mathrm{Fe}, 2.0 \mathrm{mg} \mathrm{L}^{-1}$ $\mathrm{Mn}$, and $1.0 \mathrm{mg} \mathrm{L}^{-1} \mathrm{Zn}$ and recovery tests were performed to all fractions studied.

\section{Results and Discussion}

\section{Organic matter content and $\mathrm{pH}$}

The ABE profile analysed reaches beyond $150 \mathrm{~cm}$ deep and presented an A1 horizon with $12 \mathrm{~cm}$ thick, black color, some ceramic fragments and many fine roots. The A2 horizon presented a thickness of $35 \mathrm{~cm}$, dark brown color, some ceramic fragments, coal, and many fine roots. The A3 horizon presented a thickness of $73 \mathrm{~cm}$, very dark grayish brown, some ceramic fragments and coal. While the horizons of transition $\mathrm{AB}$ and $\mathrm{BA}$ occupy the depth 
range between 75 and $130 \mathrm{~cm}$ and their colors range from yellowish brown to dark brown, respectively. The B horizon extends beyond $150 \mathrm{~cm}$ and showed a yellowish brown color. The $\mathrm{pH}$ and organic matter content determined in terra preta soil samples are presented in Table 2. The terra preta soil profile had $\mathrm{pH}$ values in the range from 4.97 to 6.07. These soils are classified as from high acidity to weak acidity, and the values increase with depth. In relation to organic matter content, the values obtained for the soils studied were greater than $76.31 \mathrm{~g} \mathrm{~kg}^{-1}$. These values are higher than those obtained by Lemos et al. ${ }^{20}$ from areas with $\mathrm{ABE}$ in Ilha de Terra site in the Caxiuanã region (PA) and were also higher than values found in the high concentration class, according to Tomé Jr. ${ }^{21}$

Table 2. Chemical soil attributes

\begin{tabular}{lcc}
\hline Samples & $\mathrm{pH} \pm \mathrm{SD}^{\mathrm{a}}$ & $\begin{array}{c}\mathrm{O} . \mathrm{M} . \pm \mathrm{SD}^{\mathrm{a}} / \\
\left(\mathrm{g} \mathrm{kg}^{-1}\right)\end{array}$ \\
\hline $\mathrm{A} 1$ & $4.97 \pm 0.01$ & $80.10 \pm 5.35$ \\
$\mathrm{~A} 2$ & $5.57 \pm 0.01$ & $81.95 \pm 4.22$ \\
$\mathrm{~A} 3$ & $5.90 \pm 0.01$ & $80.15 \pm 1.17$ \\
$\mathrm{AB}$ & $6.08 \pm 0.01$ & $76.31 \pm 0.14$ \\
$\mathrm{BA}$ & $5.67 \pm 0.02$ & $81.55 \pm 0.84$ \\
B & $5.52 \pm 0.02$ & $81.80 \pm 1.17$ \\
\hline
\end{tabular}

${ }^{\mathrm{a}} \mathrm{SD}=$ standard deviation $(\mathrm{n}=3)$.

\section{Distribution of metals in the ABE profile}

Sequential extraction is useful to indirectly assess the potential mobility and availability of metals in soils. Assuming that availability is related to solubility, it can be inferred that the metal availability decreases in the following order: water-soluble $>$ exchangeable $>$ carbonate $>$ Fe-Mn oxides $>$ organic $>$ residual. This order provides only qualitative information about the metal availability. It can also be inferred that the metal in the non-residual fraction is more available than the metal associated to the residual fraction. The non-residual fraction is the sum of all the fractions less the residual fraction. ${ }^{19}$

\section{Copper}

The result of the percentage distribution among the copper forms held in the ABE profile (Figure 2) indicates that this element was recovered (39.70-62.48\%) in the residual fraction (F6) and in the fraction bound to organic compounds (F5) (34.90-53.47\%). A low $\mathrm{Cu}$ percentage (2.16-5.82\%) was found in the fraction bound to Fe-Mn oxides (F4). The $\mathrm{Cu}$ contents in the fractions of water-soluble (F1), exchangeable (F2), and associated to carbonates (F3) were below of the limit of detection, except for the water-soluble fraction of sample $A_{1}(0.98 \%$ of total $\mathrm{Cu}$ ).

The high $\mathrm{Cu}$ content obtained in the residual and organic soil fractions has been reported by other authors. ${ }^{19,22,23}$ This association of copper with the organic fraction confirms the ability of this metal to form stable complexes with organic matter through reactions with $\mathrm{COOH}$ groups and phenolic $\mathrm{OH} .{ }^{24}$

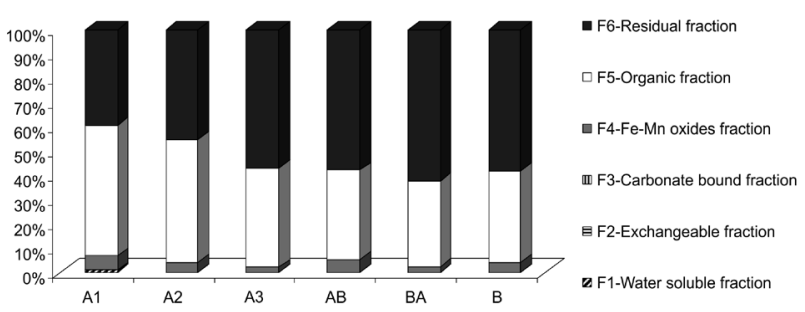

Figure 2. Percentage distribution of copper in soil chemical fractions.

Table 3 shows the $\mathrm{Cu}$ contents that were extracted from fractions of the ABE profile. It can be observed that in the fractions associated to Fe-Mn oxides, the organic matter and residual were obtained higher extractions in the $\mathrm{A}_{2}$ horizon. In the water-soluble fraction, only a low $\mathrm{Cu}$ content was detected in the $\mathrm{A}_{1}$ horizon.

In the $\mathrm{A}_{1}$ and $\mathrm{A}_{2}$ surface horizons, it was noticeable that there is a greater affinity of $\mathrm{Cu}$ for the fraction associated with organic compounds, while in the $\mathrm{A}_{3}, \mathrm{AB}, \mathrm{BA}$, and $\mathrm{B}$ subsurface horizons the affinity is for the residual fraction. As the ABE profile deepens, copper becomes more stable, or unavailable to plants. About the level of toxicity to plants, $\mathrm{Cu}$ levels obtained in the sum of fractions F1, F2, F3, F4, and F5 showed adequate levels. ${ }^{25}$

According to Wedepohl, ${ }^{26}$ in the upper continental crust, $\mathrm{Cu}$ presents a total content of $14.30 \mathrm{mg} \mathrm{kg}^{-1}$ soil. Taking this value as reference, it can be observed that the levels found in the sum of fractions are in agreement with this value.

Analysis of coefficient of variation for all fractions studied showed variations between $53.39 \%$ for fraction bound of Fe-Mn oxides to $26.58 \%$ for residual fraction, evidencing the variability of $\mathrm{Cu}$, along the soil profile.

The amount of $\mathrm{Cu}$ found in the non-residual fractions ranged from $37.52 \%$ in the BA horizon to $60.30 \%$ in the $\mathrm{A}_{1}$ horizon. These data are compatible with results obtained for $\mathrm{Cu}$ available from other sites of the ABE. ${ }^{27,28}$ Among the non-residual fractions, the fraction bound to organic matter had the greatest levels of $\mathrm{Cu}$ extracted throughout the ABE profile. It can be inferred that the availability of this element in the soil depends on the organic matter content. 
Table 3. Content of copper $\left(\mathrm{mg} \mathrm{kg}^{-1} \pm \mathrm{SD}^{\mathrm{a}}\right)$ extracted in each fraction of soil samples

\begin{tabular}{|c|c|c|c|c|c|c|}
\hline \multirow[b]{2}{*}{ Fraction } & \multicolumn{6}{|c|}{ Soil profile } \\
\hline & A1 & $\mathrm{A} 2$ & A3 & $\mathrm{AB}$ & BA & $\mathrm{B}$ \\
\hline Water soluble & $0.07 \pm 0.02$ & $<0.01 *$ & $<0.01 *$ & $<0.01 *$ & $<0.01 *$ & $<0.01 *$ \\
\hline Exchangeable & $<0.01 *$ & $<0.01 *$ & $<0.01 *$ & $<0.01 *$ & $<0.01^{*}$ & $<0.01^{*}$ \\
\hline Carbonate & $<0.01 *$ & $<0.01 *$ & $<0.01 *$ & $<0.01 *$ & $<0.01 *$ & $<0.01 *$ \\
\hline Fe-Mn oxide & $0.45 \pm 0.06$ & $0.45 \pm 0.04$ & $0.16 \pm 0.04$ & $0.29 \pm 0.04$ & $0.13 \pm 0.07$ & $0.16 \pm 0.01$ \\
\hline Organic & $4.10 \pm 0.32$ & $5.38 \pm 0.94$ & $3.11 \pm 0.92$ & $1.88 \pm 0.06$ & $1.98 \pm 0.11$ & $1.50 \pm 0.15$ \\
\hline Residual & $3.04 \pm 0.03$ & $4.85 \pm 0.45$ & $4.35 \pm 0.12$ & $2.99 \pm 0.40$ & $3.51 \pm 0.02$ & $2.34 \pm 0.26$ \\
\hline Sum of all fractions & 7.68 & 10.68 & 7.63 & 5.17 & 5.63 & 4.01 \\
\hline Non-residual / (\%) & 60.30 & 54.53 & 42.97 & 42.04 & 37.52 & 41.51 \\
\hline Residual / (\%) & 39.70 & 45.47 & 57.03 & 57.96 & 62.48 & 58.49 \\
\hline
\end{tabular}

${ }^{\mathrm{a}} \mathrm{SD}=$ standard deviation $(\mathrm{n}=3)$; *LOD (limit of detection) $/\left(\mathrm{mg} \mathrm{L}^{-1}\right)$.

Iron

The result of the percentage distribution between the forms of Fe obtained in the ABE profile (Figure 3) shows that the residual form (F6) is dominant, with percentages ranging from 80.18 to $89.34 \%$. A significant proportion of $\mathrm{Fe}$ in the soil profiles (8.99 to $17.29 \%$ ) was obtained in the fraction associated with Fe-Mn oxides (F4). This relationship was expected, since this element is found in soil, mainly in the forms of oxides and hydroxides. ${ }^{29}$

In the water-soluble fraction (F1), a low percentage of total $\mathrm{Fe}(0.13$ to $2.42 \%)$ was obtained in the studied profile. However, in the form bound to organic matter (F4), less than $0.40 \%$ of the total $\mathrm{Fe}$ was found, while in exchangeable fractions (F2) and those associated with carbonate (F3), the percentages were $<0.28 \%$.

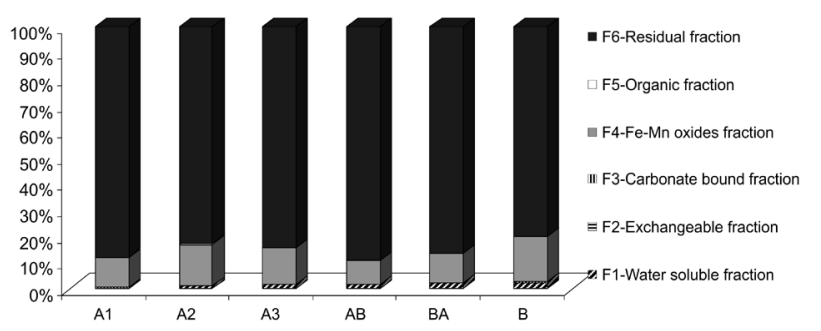

Figure 3. Percentage distribution of iron in soil chemical fractions.

Table 4 shows the Fe contents obtained in fractions from the ABE profile. It was observed that in water-soluble, exchangeable, and residual fractions, the highest total $\mathrm{Fe}$ contents were obtained in the AB horizon. In the fraction bound to carbonates, a higher $\mathrm{Fe}$ extraction was obtained in the $\mathrm{A}_{1}$ horizon, with its amount decreasing with depth in the fraction.

For fractions associated with Fe-Mn oxides and organic matter, major extractions were obtained in the $\mathrm{A}_{2}$ horizon.
About the levels of toxicity to plants, Fe levels obtained in the sum of fractions F1, F2, F3, F4, and F5 showed adequate levels..$^{30}$

According to the value found in the upper continental crust, ${ }^{26}$ iron has a total content of $30.890 \mathrm{mg} \mathrm{kg}^{-1}$ soil, and considering this value as reference, it may be noted that the levels found in the sum of fractions in the studied profile are in accordance with this value.

The coefficient of variation for almost all fractions remained on area high dispersion, ranging from $13.70 \%$ to $76.0 \%$, evidencing the variability of Fe among fractions, along the soil profile.

The Fe levels present in the non-residual fractions showed variations between $10.66 \%$ in the $\mathrm{AB}$ horizon and $19.82 \%$ in the $\mathrm{B}$ horizon. Among the non-residual fractions, the fraction bound to Fe-Mn oxides showed the highest Fe content throughout the profile. Therefore, this fraction is the immediate reserve for the supply of this element in the ABE profile.

\section{Manganese}

The result of the percentage distribution between the forms of Mn found in the ABE profile (Figure 4) shows that this element had the most even distribution among the fractions analysed. Considerable quantities of total Mn were found in residual (F6), bound to Fe-Mn oxides (F4) and to organic matter fractions (F5), with percentages ranging from 18.19 to $60.06 \%, 8.99$ to $56.18 \%$, and 0.92 to $55.71 \%$, respectively.

It may be noted that the lowest distribution of total Mn was obtained in fractions which were bound to carbonates (F3) (4.52-12.65\%) and water-soluble (F1) (1.44-3.43\%). The contents in the exchangeable fraction (F2) were below the detection limit, with the exception of the sample from the $\mathrm{A}_{1}$ surface horizon, which showed $16.06 \%$ of total Mn. 
Table 4. Content of iron $\left(\mathrm{mg} \mathrm{kg}^{-1} \pm \mathrm{SD}^{\mathrm{a}}\right)$ extracted in each fraction of soil samples

\begin{tabular}{|c|c|c|c|c|c|c|}
\hline \multirow[b]{2}{*}{ Fraction } & \multicolumn{6}{|c|}{ Soil profile } \\
\hline & A1 & $\mathrm{A} 2$ & A3 & $\mathrm{AB}$ & $\mathrm{BA}$ & $\mathrm{B}$ \\
\hline Water soluble & $15.08 \pm 0.64$ & $112.37 \pm 1.19$ & $170.79 \pm 1.42$ & $292.98 \pm 69.32$ & $272.37 \pm 47.55$ & $192.31 \pm 0.93$ \\
\hline Exchangeable & $2.38 \pm 0.15$ & $<0.12 *$ & $0.42 \pm 0.10$ & $2.89 \pm 0.11$ & $2.68 \pm 0.02$ & $2.10 \pm 0.07$ \\
\hline Carbonate & $31.68 \pm 0.70$ & $21.65 \pm 0.72$ & $18.19 \pm 0.46$ & $10.17 \pm 0.21$ & $8.02 \pm 0.65$ & $4.86 \pm 0.39$ \\
\hline Fe-Mn oxide & $1265.39 \pm 227.55$ & $1818.12 \pm 345.53$ & $1497.66 \pm 131.49$ & $1749.72 \pm 8.19$ & $1599.41 \pm 32.23$ & $1376.43 \pm 57.17$ \\
\hline Organic & $34.12 \pm 2.47$ & $46.03 \pm 13.08$ & $21.25 \pm 0.64$ & $19.07 \pm 1.03$ & $5.79 \pm 0.25$ & $2.68 \pm 0.06$ \\
\hline Residual & $9847.76 \pm 671.20$ & $9507.49 \pm 968.56$ & $9241.05 \pm 662.06$ & $17391.25 \pm 2444.06$ & $12123.86 \pm 1458.76$ & $6384.52 \pm 815.11$ \\
\hline Sum of all fractions & 11196.42 & 11505.66 & 10949.37 & 19466.08 & 14012.14 & 7962.89 \\
\hline Non-residual / (\%) & 12.05 & 17.37 & 15.60 & 10.66 & 13.48 & 19.82 \\
\hline Residual / (\%) & 87.95 & 82.63 & 84.40 & 89.34 & 86.52 & 80.18 \\
\hline
\end{tabular}

${ }^{\mathrm{a}} \mathrm{SD}=$ standard deviation $(\mathrm{n}=3)$; *LOD (limit of detection) $/\left(\mathrm{mg} \mathrm{L}^{-1}\right)$.

Soil $\mathrm{pH}$ is, in most cases, the main factor controlling the availability of micronutrients for plants ${ }^{31}$ and the availability of these metals is relatively low at $\mathrm{pH}$ values around 6 to $7 .^{32}$ About the levels of toxicity to plants, Mn levels obtained in the sum of fractions F1, F2, F3, F4, and F5 showed adequate levels. ${ }^{25}$

It can be observed that in the fraction bound to organic matter, the percentages of total $\mathrm{Mn}$ increased with the profile depth, which may be due to $\mathrm{pH}$ increases along the ABE profile. Under these $\mathrm{pH}$ conditions (around 6) the amount of Mn adsorbed by the organic matter is generally high, and there are usually low contents of exchangeable forms and high contents of organic forms and oxides, ${ }^{33,34}$ which agrees with the results of this study.

In the $\mathrm{A}_{1}$ and $\mathrm{A}_{2}$ horizons, the sum of total $\mathrm{Mn}$ obtained in F1, F2, and F3 was higher than $16.00 \%$. This suggests that $\mathrm{Mn}$ in the surface horizons may be highly available in the $\mathrm{ABE}$ profile.

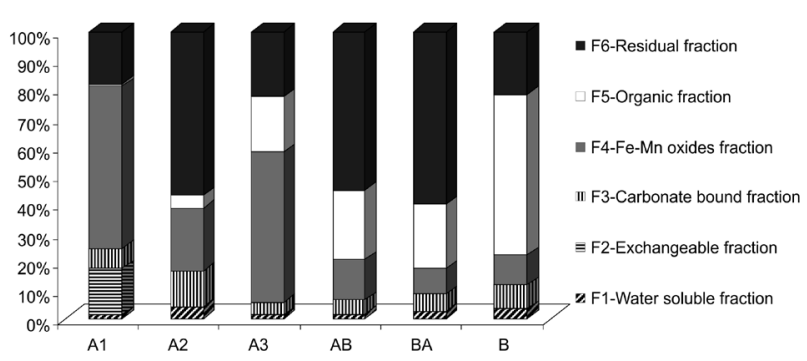

Figure 4. Percentage distribution of manganese in soil chemical fractions.

Table 5 presents the Mn contents obtained in fractions from the $\mathrm{ABE}$ profile. It was observed that the $\mathrm{A}_{1}$ horizon showed the highest total Mn content in the fractions which were water-soluble, exchangeable, and bound to carbonates and to Fe-Mn oxides, and its amount decreased with depth in the fractions.
In the fraction bound to organic matter, the highest extraction was for the $\mathrm{A}_{3}$ horizon, while in the residual fraction, a higher extraction was obtained for the $\mathrm{A}_{2}$ horizon.

In the upper continental crust, ${ }^{26}$ manganese presents a total content of $527.00 \mathrm{mg} \mathrm{kg}^{-1}$ soil. Taking this value as reference, it can be observed that the levels found in the sum of fractions are in agreement with this value.

The coefficient of variation for all fractions remained with high dispersion, ranging from $47.71 \%$ to $131.0 \%$, showed the great variability of $\mathrm{Mn}$ among fractions and along of the soil profile.

The Mn levels in the residual fractions showed variations from $39.94 \%$ in the BA horizon to $81.81 \%$ in the $A_{1}$ horizon. These data were lower results obtained for Mn available from other sites of the ABE. ${ }^{27,28}$ Among the non-residual fractions, the fraction bound to $\mathrm{Fe}-\mathrm{Mn}$ oxides showed the highest $\mathrm{Mn}$ concentrations in the $\mathrm{A}_{1}$, $\mathrm{A}_{2}$, and $\mathrm{A}_{3}$ horizons, while in the deeper $\mathrm{AB}, \mathrm{BA}$, and $\mathrm{B}$ horizons, major extractions occurred in fractions bound to the organic matter.

It can be inferred that in surface horizons, this element is available from Fe-Mn oxides, and with increasing depth in the ABE profile, manganese is most available from the organic matter.

\section{Zinc}

The result of the percentage distribution among the forms of zinc obtained in the ABE profile (Figure 5) indicates that this element was predominant in the residual fraction (F6) throughout the soil profile, with percentages ranging from $38.48 \%$ to $73.29 \%$. Ma and $\mathrm{Rao}^{19}$ found that the majority of zinc in the soil was associated with the residual fraction. This high $\mathrm{Zn}$ percentage in the residual fraction probably reflects the greater tendency of $\mathrm{Zn}$ to become unavailable in the soil. ${ }^{19}$ 
Table 5. Content of manganese $\left(\mathrm{mg} \mathrm{kg}^{-1} \pm \mathrm{SD}^{\mathrm{a}}\right)$ extracted in each fraction of soil samples

\begin{tabular}{|c|c|c|c|c|c|c|}
\hline \multirow[b]{2}{*}{ Fraction } & \multicolumn{6}{|c|}{ Soil profile } \\
\hline & A1 & A2 & A3 & $\mathrm{AB}$ & BA & B \\
\hline Water soluble & $1.33 \pm 0.29$ & $1.28 \pm 0.14$ & $0.80 \pm 0.09$ & $0.40 \pm 0.01$ & $0.41 \pm 0.03$ & $0.28 \pm 0.02$ \\
\hline Exchangeable & $13.86 \pm 0.36$ & $<0.05^{*}$ & $<0.05^{*}$ & $<0.05^{*}$ & $<0.05^{*}$ & $<0.05^{*}$ \\
\hline Carbonate & $6.15 \pm 0.02$ & $3.82 \pm 0.07$ & $2.51 \pm 0.17$ & $1.05 \pm 0.05$ & $0.94 \pm 0.07$ & $0.69 \pm 0.03$ \\
\hline Fe-Mn oxide & $48.51 \pm 3.45$ & $6.52 \pm 0.27$ & $28.94 \pm 2.84$ & $3.10 \pm 0.17$ & $1.41 \pm 0.38$ & $0.83 \pm 0.03$ \\
\hline Organic & $0.79 \pm 0.10$ & $1.38 \pm 0.14$ & $10.68 \pm 0.52$ & $5.29 \pm 0.14$ & $3.49 \pm 0.29$ & $4.54 \pm 0.03$ \\
\hline Residual & $15.70 \pm 1.10$ & $17.18 \pm 0.29$ & $12.64 \pm 0.97$ & $12.20 \pm 1.14$ & $9.40 \pm 0.79$ & $1.80 \pm 0.14$ \\
\hline Sum of all fractions & 86.35 & 30.19 & 55.58 & 22.04 & 15.65 & 8.15 \\
\hline Non-residual / (\%) & 81.81 & 43.07 & 77.24 & 44.64 & 39.94 & 77.81 \\
\hline Residual / (\%) & 18.18 & 56.92 & 22.75 & 55.35 & 60.05 & 22.18 \\
\hline
\end{tabular}

${ }^{\mathrm{a}} \mathrm{SD}=$ standard deviation $(\mathrm{n}=3)$; *LOD (limit of detection $) /\left(\mathrm{mg} \mathrm{L}^{-1}\right)$.

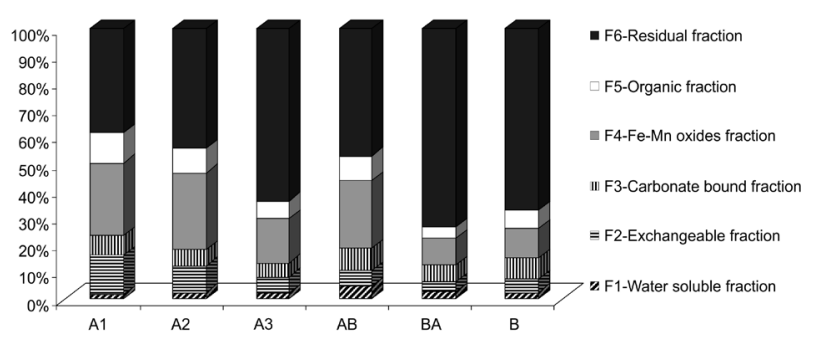

Figure 5. Percentage distribution of zinc in soil chemical fractions.

A considerable proportion of $\mathrm{Zn}$ in the soil profile (9.93 to $28.31 \%$ ) was found in the fraction bound to $\mathrm{Fe}-\mathrm{Mn}$ oxides (F4).

The contribution of organic matter (F5) to the $\mathrm{Zn}$ retention in the soil profile ranged from 4.37 to $11.24 \%$, while the participation of forms which were associated with carbonate (F3), exchangeable (F2), and water-soluble (F1) ranged from 5.18 to $8.06 \%, 3.67$ to $14.58 \%$, and 1.46 to $4.69 \%$, respectively. In relation to mobility and availability,
$\mathrm{Zn}$ is highly available in the ABE profile, since over $12.00 \%$ of the total $\mathrm{Zn}$ was found in the sum of F1, F2, and F3. About the level of toxicity to plants, $\mathrm{Zn}$ levels obtained in the sum of fractions F1, F2, F3, F4, and F5 showed normal levels with the exception of the samples from the $\mathrm{A}_{1}$ and $\mathrm{A}_{2}$ surface horizons reach toxic levels $\left(>15 \mathrm{mg} \mathrm{kg}^{-1}\right)^{25}$ which can be harmful to plant growth.

Table 6 shows the $\mathrm{Zn}$ contents obtained in fractions from the ABE profile. It can be observed that the fractions which were soluble in water, bound to carbonates, bound to Fe-Mn oxides, and bound to organic matter showed a higher extraction in the $\mathrm{A}_{2}$ horizon, while in the exchangeable and residual fractions, higher extractions were obtained in the $A_{1}$ and $A_{3}$ surface horizon, respectively. The $\mathrm{Zn}$ levels extracted in most fractions decreased with depth. The $\mathrm{Zn}$ levels obtained in the sum of the fractions are in agreement with the value of $52.00 \mathrm{mg} \mathrm{kg}^{-1}$ found in the upper continental crust. ${ }^{26}$ The coefficient of variation for almost all fractions remained with high dispersion, ranging

Table 6. Content of zinc $\left(\mathrm{mg} \mathrm{kg}^{-1} \pm \mathrm{SD}^{\mathrm{a}}\right)$ extracted in each fraction of soil samples

\begin{tabular}{|c|c|c|c|c|c|c|}
\hline \multirow[b]{2}{*}{ Fraction } & \multicolumn{6}{|c|}{ Soil profile } \\
\hline & A1 & A2 & A3 & $\mathrm{AB}$ & BA & $\mathrm{B}$ \\
\hline Water soluble & $0.48 \pm 0.06$ & $0.97 \pm 0.05$ & $0.84 \pm 0.05$ & $0.76 \pm 0.05$ & $0.51 \pm 0.08$ & $0.39 \pm 0.06$ \\
\hline Exchangeable & $4.86 \pm 0.03$ & $4.21 \pm 0.10$ & $2.58 \pm 0.36$ & $0.93 \pm 0.11$ & $0.78 \pm 0.09$ & $0.84 \pm 0.11$ \\
\hline Carbonate & $2.38 \pm 0.25$ & $2.61 \pm 0.19$ & $2.21 \pm 0.16$ & $1.31 \pm 0.08$ & $1.34 \pm 0.04$ & $1.37 \pm 0.03$ \\
\hline Fe-Mn oxide & $9.03 \pm 0.36$ & $12.05 \pm 0.53$ & $6.97 \pm 0.53$ & $4.10 \pm 0.23$ & $2.10 \pm 0.26$ & $1.92 \pm 0.03$ \\
\hline Organic & $3.75 \pm 0.16$ & $3.87 \pm 0.14$ & $2.80 \pm 0.27$ & $1.48 \pm 0.11$ & $0.92 \pm 0.06$ & $1.23 \pm 0.01$ \\
\hline Residual & $12.82 \pm 5.35$ & $18.86 \pm 3.24$ & $27.14 \pm 4.95$ & $7.66 \pm 2.01$ & $15.50 \pm 0.76$ & $11.68 \pm 2.92$ \\
\hline Sum of all fractions & 33.32 & 42.57 & 42.57 & 16.25 & 21.15 & 17.43 \\
\hline Non-residual / (\%) & 61.51 & 55.68 & 36.16 & 52.81 & 26.71 & 33.00 \\
\hline Residual / (\%) & 38.48 & 44.31 & 63.83 & 47.18 & 73.29 & 66.99 \\
\hline
\end{tabular}

${ }^{\mathrm{a}} \mathrm{SD}=$ standard deviation $(\mathrm{n}=3) ;$ * LOD (limit of detection) $/\left(\mathrm{mg} \mathrm{L}^{-1}\right)$. 
from $31.80 \%$ to $76.92 \%$, evidencing the great variability of $\mathrm{Zn}$ between fractions along the soil profile.

The $\mathrm{Zn}$ content present in non-residual fractions showed variations between $26.71 \%$ in the BA horizon and $61.52 \%$ in the $\mathrm{A}_{1}$ horizon. This data showed the highest results for $\mathrm{Zn}$ available from other sites of the ABE. ${ }^{27,28}$ Among the non-residual fractions, the fraction bound to Fe-Mn oxides obtained the highest $\mathrm{Zn}$ levels throughout the ABE profile. This may be due to the high constant stability of $\mathrm{Zn}$ oxides in soils. ${ }^{18}$ Several studies have reported the dominance of Fe-Mn oxides bound to $\mathrm{Zn} .{ }^{11,12,19,22,23,35} \mathrm{It}$ can be inferred that this element is preferentially available from $\mathrm{Fe}-\mathrm{Mn}$ oxides.

\section{Recovery}

The recoveries of $4.00 \mathrm{mg} \mathrm{L}^{-1} \mathrm{Cu}, 9.00 \mathrm{mg} \mathrm{L}^{-1} \mathrm{Fe}$, $2.00 \mathrm{mg} \mathrm{L}^{-1} \mathrm{Mn}$, and $1.00 \mathrm{mg} \mathrm{L}^{-1} \mathrm{Zn}$ added in the fractions ranged from 80.30 to $95.50 \%$ for $\mathrm{Cu}, 90.20$ to $96.50 \%$ for $\mathrm{Fe}$, 83.70 to $103.70 \%$ for $\mathrm{Mn}$, and from 89.20 to $104.20 \%$ for $\mathrm{Zn}$.

\section{Conclusions}

The sequential extractions showed that the highest $\mathrm{Cu}$, $\mathrm{Fe}, \mathrm{Mn}$, and $\mathrm{Zn}$ concentrations were found in the residual fraction for most samples and the sums of the non-residual fractions showed in appropriate levels for $\mathrm{Cu}, \mathrm{Fe}$ and $\mathrm{Mn}$, while $\mathrm{Zn}$ toxic levels presented in surface horizons. These data associated with high levels of organic matter show that this ABE soil profile investigated, still preserves its relative high fertility.

This study showed that the fractionation of elements found in the ABE profile has a similar behaviour, because among non-residual fractions, the fraction bound to Fe-Mn oxides was the most significant for the elements, except for $\mathrm{Cu}$, which predominated in the fraction bound to organic compounds, and the exchangeable fraction was the least significant for the elements, except for $\mathrm{Zn}$, which was less associated with the water-soluble fraction.

\section{Acknowledgments}

The authors are grateful to Conselho Nacional de Desenvolvimento Científico e Tecnológico (CNPq) for research funds and fellowships. K. G. F. and C. S. T. M. also are thankful to Dr. Dulcidéia da Conceição Palheta (UFRA, Pará, Brazil) by use on the FAAS.

\section{References}

1. Lima, H. N.; Schaefer, C. E. R.; Melo, J. W. V.; Gilkes, R. J.; Ker, J. C.; Geoderma 2002, 110, 1.
2. Cunha, T. J. F.; Madari, B. E.; Benites, V. M.; Canellas, L. P.; Novotny, E. H.; Moutta, R. O.; Trompowsky, P. M.; Santos, G. A.; Acta Amaz. 2007, 37, 91.

3. Éden, M. J.; Bray, W.; Herrera, L.; Mcewan, C.; Am. Antiq. 1984, 49, 125.

4. Smith, N. J. H.; Ann. Assoc. Am. Geogr. 1980, 70, 553.

5. Woods, W. I.; Mccann, J. M.; El Origen y Persistencia de las Tierras Negras de la Amazonia; Abya Ayala : Quito, Ecuador, 2001, p. 23.

6. Novotny, E. H.; Hayes, M. H. B.; Madari, B. E.; Bonagamba, T. J.; deAzevedo, E. R.; de Souza, A. A.; Song, G.; Nogueira, C. M.; Mangrich, A. S.; J. Braz. Chem. Soc. 2009, 20, 1003.

7. Falcão, N. P. S.; Comerford, N.; Lehman, J. In Amazonian Dark Earths: Origin, Properties, Management; Lehmann, J.; Kern, D. C.; Glaser, B.; Woods, W. I., eds., Kluwer Academic Publishers: Netherlands, 2003, p. 255.

8. Gonçalves Junior, A. C.; Luchese, E. B.; Lenzi, E.; Quim. Nova 2000, 23, 173.

9. Tüzen, M.; Microchem. J. 2003, 74, 289.

10. Sposito, G.; Lund, L. J.; Chang, A. C.; Soil Sci. Soc. Am. J. 1982, 46, 260.

11. Tessier, A.; Campbell, P. G. C.; Bisson, M.; Anal. Chem. 1979, $51,844$.

12. Kabala, C.; Sing, B. R.; J. Environ. Qual. 2001, 30, 485.

13. Gleyzes, C.; Tellier. S.; Astruc, M.; Trends Anal. Chem. 2002, $21,451$.

14. Kersten, M.; Forstner, U. In Trace Elements Speciation: Analytical Methods and Problems; Batley, G. E., ed., CRC Press: Boca Raton, Florida, 1989, p. 245.

15. Costa, A. C. S. da; Almeida, V. de C.; Lenzi, E.; Nozaki, J.; Quim. Nova 2002, 25, 548.

16. Lemos, A.; Santos, P. B.; Manual de Descrição e Coleta de Solos em Campo, SBCS/SNLCS: Campinas, SP, Brasil, 1996, p. 46.

17. Munsell Colors Company; Munsell Soil Colors Charts, Baltimore, 2000.

18. Embrapa; Análise Química para Avaliação da Fertilidade do Solo. Métodos utilizados na Embrapa Solos, Documento No. 3, 1998. Available: www.esolos-d09bgw.cnps.embrapa.br/ blogs/paqlf/wp-content/uploads/2008/08/analises_quimicas_ fertilidade.pdf accessed in April 2009.

19. Ma, L. Q.; Rao, G. N.; J. Environ. Qual. 1997, 26, 259.

20. Lemos, V. P.; Costa, M. L., Gurjão, R. S.; Kern, D. C.; Mescouto, C. S. T.; Lima, W. T. S.; Rev. Esc. Minas 2009, 62, 139. Available: www.rem.com.br/seer_antigo/index.php/ Escola/issue/view/22/showToc accessed in January 2010.

21. Tomé Jr., J. B.; Manual para Interpretação de Análise de Solo, Agropecuária: Guaíba, Rio Grande do Sul, Brasil, 1997.

22. Iwegbue, C. M. A.; Waste Manage. Res. 2007, 25, 585.

23. Harrison, R. M.; Laxen, D. P. H.; Wilson, S.; Environ. Sci. Technol. 1981, 15, 1378. 
24. Gomes, P. C.; Fontes, M. P. F.; Costa, L. M.; Mendonça, E. S.; Rev. Bras. Cienc. Solo 1997, 21, 543.

25. Kabata-Pendias, A.; Pendias, H.; Trace Elements in Soils and Plants, CRR Press: Boca Raton, 2000, p. 403.

26. Wedepohl, K. H.; Geochim. Cosmochim. Acta 1995, 59, 1217.

27. Costa, M. L.; Kern, D. C.; J. Geochem. Explor. 1999, 66, 369.

28. Carmo, M. S.; Costa, M. L.; Kern, D. C.; Contribuições à Geologia da Amazônia, SBG: Belém, 2007, 5, p.143.

29. Amberger, A.; Pflanzenernährung, Verlag Eugen Ulmer: Stuttgart, 1988, p. 264.

30. O'Neil, P.; Environmental Chemistry; $2^{\text {nd }}$ ed., Chapmam and Hall: London, 1994, p. 151.
31. Chlopecka, A.; Adriano, D. C.; Environ. Sci. Technol. 1996, 30, 3294.

32. Kabata-Pendias, A.; Pendias, H.; Trace Elements in Soils and Plants, CRR Press: Boca Raton, 1987, p. 315.

33. Bibak, A.; Commun. Soil Sci. Plant Anal.1994, 25, 3229.

34. Shuman, L. M.; Soil Sci. Soc. Am. J. 1986, 50, 1236.

35. Zaghloul, A. M.; El-Dewinty, C.; Youssef, R. A.; J. Appl. Sci. Res. 2006, 2, 284. 